\title{
IDENTIFIKASI POTENSI EKONOMI KECAMATAN TANJUNGSARI KABUPATEN GUNUNGKIDUL YOGYAKARTA
}

\author{
Romi Bhakti Hartarto \\ Fakultas Ekonomi dan Bisnis, Universitas Muhammadiyah Yogyakarta \\ Jalan Lingkar Selatan, Bantul, Yogyakarta 55183 Indonesia, Phone +62-274-387656 \\ E-mail Korespondensi: romi.hartarto@gmail.com
}

Naskah Diterima: November 2015; Disetujui: Februari 2016

\begin{abstract}
The intention of regional government of Special Region of Yogyakarta to make south area as the front page of regional economic development has been initiated. As one subdistrict located in the south area of Gunungkidul regency, Tanjungsari subdistrict has several prospects on economy, tourism, and resources due to its strategic and direct position near the Hindia Ocean and Southern Traffic Lane. This study aims to mapping economic potential based upon leading sectors as identified by Location Quotient $(L Q)$ method and Klassen typology which is employed to characterize the economic pattern and structure. Based on LQ analysis, both manufacturing and construction sectors are the leading sectors which need to develop in advance since they are the supporting sectors nowadays and in the future. Meanwhile, there exists a shift in economic pattern from developing region to underdeveloped region according to Klassen typology.

Keywords: economic development, leading sector, LQ, klassen typology

JEL Classification: R11, R58
\end{abstract}

Abstrak: Visi Pemerintah Daerah Istimewa Yogyakarta untuk menjadikan kawasan selatan
sebagai halaman depan bagi pembangunan ekonomi daerah sudah mulai dicanangkan. Sebagai
salah satu kecamatan yang terletak di kawasan selatan Kabupaten Gunungkidul, Kecamatan
Tanjungsari memiliki berbagai potensi ekonomi, wisata, dan sumber daya mengingat letaknya
yang berbatasan langsung dengan Samudera Hindia dan dilalui Jalan Jalur Lintas Selatan.
Penelitian ini bermaksud memetakan potensi ekonomi berdasarkan sektor-sektor unggulan yang
diidentifikasi melalui metode Location Quotient (LQ) dan tipologi Klassen untuk mengetahui
pola dan struktur ekonomi. Berdasarkan analisis LQ, sektor industri pengolahan dan bangunan
menjadi sektor unggulan yang perlu dikembangkan karena merupakan sektor penunjang baik di
masa sekarang maupun mendatang. Sementara itu, terdapat pergeseran pola perekonomian dari
kawasan berkembang menjadi kawasan tertinggal menurut tipologi Klassen. Keywords: pembangunan ekonomi, sektor unggulan, $L Q$, tipologi klassen Klasifikasi JEL: R11, R58 


\section{PENDAHULUAN}

Pembangunan ekonomi meliputi segala upaya dan kebijakan dengan tujuan untuk meningkatkan standar hidup masyarakat, memperbanyak lapangan kerja baru, mengurangi ketimpangan distribusi pendapatan, mempererat hubungan ekonomi regional, dan menggeser aktivitas ekonomi dari sektor pertanian ke sektor industri dan jasa yang memiliki nilai tambah lebih tinggi. Perencanaan pembangunan daerah yang utuh hendaknya dimulai pada tingkat kecamatan yang merupakan daerah administratif di bawah kabupaten atau kota yang terdiri dari desa-desa atau kelurahan-kelurahan. Mengingat setiap daerah memiliki keberagaman potensi, baik dari sisi sumber daya alam, manusianya, maupun kondisi geografis, maka kebijakan pembangunan daerah tentu saja tidak secara langsung mengadopsi kebijakan nasional, daerah induk pada tingkat administratif yang lebih tinggi, atau daerah lain yang dianggap berhasil. Sehingga dibutuhkan kebijakan pembangunan yang didasarkan pada kekhasan daerah sesuai dengan potensi sumber daya lokal.

Kecamatan Tanjungsari terletak di Kabupaten Gunungkidul, Provinsi Daerah Istimewa Yogyakarta. Wilayahnya yang terletak di sebelah selatan Kabupaten Gunungkidul menjadikan kecamatan ini berbatasan langsung dengan Samudera Hindia sehingga memiliki wisata bahari yang memberikan daya tarik bagi para wisatawan dan berkontribusi terhadap perekonomian masyarakat setempat. Selain potensi wisata, Kecamatan Tanjungsari juga memiliki beberapa potensi di bidang pertanian, perikanan, dan peternakan dengan hasil olahan berupa pandan, melon, gambas, dan alga jenis ulva yang bisa dikembangkan pengolahannya untuk disinergikan dengan sektor pariwisata. Sementara dari segi geografis, kawasan ini dilewati oleh jalur lintas selatan yang diyakini dapat menggerakkan roda perekonomian Kabupaten Gunungkidul di masa datang. Terlebih Pemerintah Provinsi DIY sudah mencanangkan visi yang menjadikan kawasan selatan sebagai halaman depan pembangunan ekonomi daerah. Terlebih, Kabupaten Gunungkidul termasuk dalam kategori daerah berkembang cepat menurut penelitian Restiatun
(2009). Oleh karena itu, pengelolaan ekonomi yang mensinergikan pemanfaatan sumber daya bahari dengan sumber daya alam lainnya secara integral diharapkan dapat mengurangi kesenjangan dan meningkatkan pendapatan masyarakat Kecamatan Tanjungsari.

Potensi ekonomi dan wisata alam tersebut perlu diidentifikasi dengan jelas sehingga dapat dikembangkan untuk memberikan efek positif ke sektor lainnya. Untuk memperoleh hasil optimal berdasarkan potensi unggulan yang dimiliki, penelitian ini bermaksud untuk memetakan seluruh potensi ekonomi Kecamatan Tanjungsari secara akurat melalui analisis sektor dan sub sektor ekonomi yang berpotensi sebagai daya ungkit pengembangan wilayah. Tumbuhnya sektor ekonomi unggulan diharapkan dapat mendorong pertumbuhan sektorsektor ekonomi lainnya. Sebagai gambaran, sektor unggulan yang dimiliki oleh Kabupaten Gunungkidul menurut hasil penelitian Restiatun (2009) adalah sektor pertanian, sektor pertambangan dan penggalian, sektor bangunan, serta sektor pengangkutan dan komunikasi.

Penelitian ini menggunakan pendekatan pengembangan ekonomi lokal dengan dalih bahwa untuk menjadi kawasan yang mandiri dan berkelanjutan, kawasan tersebut harus mampu mendayagunakan sumber daya yang dimilikinya semaksimal mungkin sehingga tercipta nilai tambah dan rantai produksi yang panjang. Perekonomian lokal terbagi menjadi dua sektor, yakni basis dan non-basis. Aktivitas perekonomian pada sektor basis mampu mengekspor barang dan jasa ke luar batas wilayah perekonomian sementara sektor nonbasis hanya mampu menyediakan barang dan jasa untuk memenuhi kebutuhan masyarakat yang berada di wilayah bersangkutan. Teori basis ekonomi menyatakan bahwa makin banyak sektor basis di suatu daerah, makin bertambah pula arus pendapatan dari luar ke dalam daerah sehingga akan menaikkan permintaan akan barang dan jasa yang diproduksi oleh sektor non-basis, dan sebaliknya. Dalam hal ini, sektor basis memiliki peranan sebagai penggerak utama perekonomian wilayah melalui efek pengganda. Oleh karena itu, suatu daerah dapat berkembang jika mampu memajukan sektor basisnya (Glasson, 
1977), serta penanaman modal pada industri lokal sebagai hasil dari naiknya pendapatan industri sektor basis (Kadariah, 1985).

\section{METODE PENELITIAN}

Metode dasar yang diterapkan dalam penelitian ini adalah analisis deskriptif yang bertujuan untuk membuat gambaran suatu fenomena sosial untuk dicari hubungannya. Ada pun, pengumpulan data yang digunakan dalam penelitian ini melalui studi pustaka untuk memperdalam pemahaman konsep pengembangan kawasan dan dokumentasi data statistik terkini yang diterbitkan oleh Badan Pusat Statistik (BPS) Kabupaten Gunungkidul dalam beberapa tahun terakhir.

Sesuai dengan tujuan yang telah dirumuskan dalam penelitian ini, maka metode analisis yang digunakan meliputi analisis sektor dan subsektor ekonomi potensial melalui indikator turunan dari PDRB seperti pertumbuhan ekonomi, struktur ekonomi dan pendapatan per kapita penduduk Kecamatan Tanjungsari. Dalam hal ini, analisis location quotient (LQ) digunakan untuk menunjukkan besar kecilnya peranan suatu sektor perekonomian suatu wilayah jika dibandingkan dengan sektor yang sama pada wilayah dengan cakupan lebih besar. Metode ini digunakan untuk mengidentifikasi sektor ekonomi mana yang paling berpotensi untuk menjadi unggulan.

Metode location quotient (LQ) dibedakan menjadi dua, yakni: static location quotient (SLQ atau LQ) dan dynamic location quotient (DLQ). Dasar penggunaan teknik LQ adalah teori ekonomi basis di mana ketika industri basis itu menghasilkan barang dan jasa untuk pasar di daerah dan di luar daerah maka penjualan hasil ke luar daerah akan mendatangkan pendapatan ke daerah yang bersangkutan. Masuknya arus pendapatan akan menyebabkan naiknya konsumsi dan investasi sehingga pendapatan daerah dan kesempatan kerja ikut meningkat pada gilirannya. Ada pun, rumus penghitungan yang digunakan dalam penelitian ini adalah (Budiharsono, 2001):

$$
L Q=\frac{V_{1}^{R} / V^{R}}{V_{1} / V}
$$

dimana:
$V_{1}^{R}$ : Nilai PDRB suatu sektor tingkat kecamatan; $V^{R}$ : Nilai PDRB seluruh sektor tingkat kecamatan; $V_{1}$ : Nilai PDRB suatu sektor tingkat kabupaten; $V$ : Nilai PDRB seluruh sektor tingkat kabupaten

Berdasarkan analisis location quotient (LQ), jika nilai $L Q>1$ maka sektor tersebut potensial, yakni dapat melayani pasar baik di dalam maupun di luar Kecamatan Tanjungsari. Semakin nilai LQ lebih tinggi dari satu, semakin tinggi keunggulan komparatifnya (Cahyono dan Wijaya, 2014). Sebaliknya jika nilai LQ $<1$, maka sektor tersebut bukan potensial di mana belum mampu memenuhi permintaan pasar di Kecamatan Tanjungsari. Jika nilai $L Q=1$, sektor tersebut hanya mampu melayani pasar di Kecamatan Tanjungsari saja tanpa mampu memasarkan hasil sektor tersebut ke daerah lain.

Perubahan perekonomian lokal pada kurun waktu tertentu dapat diuji melalui Dynamic Location Quotient (DLQ) sehingga perubahan sektoral dapat diketahui. DLQ merupakan bentuk modifikasi dari SLQ dengan mengakomodasi besarnya PDRB dari nilai produksi sektor atau sub sektor dari waktu ke waktu. Naik turunnya LQ dapat dilihat untuk sektor tertentu pada dimensi waktu yang berbeda dengan formulasi sebagai berikut (Nazipawati, 2007):

$D L Q_{i j}=\left[\frac{\left(1+g_{i j}\right) /\left(1+g_{j}\right)}{\left(1+G_{i}\right) /(1+G)}\right]=\frac{I P P S_{i j}}{I P P S_{i}}$

di mana:

$D L Q_{i j}$ : Indeks potensi sektor $i$ di tingkat kecamatan/kabupaten

$g_{i j}$ : Laju pertumbuhan nilai tambah sektor dan sub sektor $i$ di daerah studi

$g_{j}$ : Rata-rata laju pertumbuhan PDRB di tingkat kecamatan/kabupaten

$G_{i}$ : Laju pertumbuhan nilai tambah sektor dan sub sektor $i$ daerah referensi

$G$ : Rata-rata pertumbuhan PDRB daerah referensi

Nilai DLQ yang dihasilkan jika lebih dari 1, maka potensi perkembangan sektor $i$ di suatu daerah lebih cepat jika dibanding dengan sektor yang sama dalam lingkup nasional. Sebaliknya, 
jika DLQ < 1, maka potensi perkembangan sektor $i$ di daerah lebih rendah jika dibanding nasional secara keseluruhan. Penggabungan antara nilai SLQ dan DLQ dapat dijadikan kriteria dalam menentukan apakah sektor ekonomi tergolong unggulan, prospektif, andalan, dan tertinggal. Ada pun kriteria yang digunakan sebagai berikut (Suyatno, 2000):

a. Jika nilai LQ dan DLQ > 1, berarti sektor tersebut akan tetap menjadi basis baik sekarang maupun di masa datang.

b. Jika nilai LQ $>1$ dan DLQ $<1$, itu artinya sektor tersebut akan bergeser dari sektor basis menjadi non basis di masa datang.

c. Jika nilai $L Q<1$ dan DLQ $>1$, maka sektor tersebut akan bergeser dari sektor non basis menjadi sektor basis di masa datang.

d. Jika nilai LQ dan DLQ < 1, maka sektor tersebut akan terus menjadi non basis baik saat ini maupun di masa datang.

Tabel 1. Penggolongan Sektor menurut SLQ dan DLQ

\begin{tabular}{ccc}
\hline Kriteria & DLQ $>\mathbf{1}$ & DLQ $<\mathbf{1}$ \\
\hline SLQ $>1$ & Unggulan & Prospektif \\
SLQ $<1$ & Andalan & Tertinggal \\
\hline
\end{tabular}

Selain kedua analisis di atas, analisis tipologi Klassen turut digunakan untuk mencari tahu gambaran pola dan struktur pertumbuhan ekonomi Kecamatan Tanjungsari dengan membagi daerah berdasarkan dua indikator ekonomi, yakni pertumbuhan ekonomi dan pendapatan per kapita daerah. Melalui indikator ini, daerah terbagi menjadi empat kelompok yakni (Rustiadi et al, 2011): (1) daerah cepat maju dan cepat tumbuh, yakni daerah dengan pertumbuhan ekonomi dan pendapatan per kapita lebih tinggi dari rata-rata kabupaten, (2) daerah maju tapi tertekan, yakni dengan pendapatan per kapita lebih tinggi namun pertumbuhan ekonominya lebih rendah dari rata-rata kabupaten, (3) daerah berkembang cepat dengan tingkat pertumbuhan tinggi namun pendapatan per kapitanya lebih rendah dari rata-rata kabupaten, dan (4) daerah tertinggal dengan tingkat pertumbuhan ekonomi dan pendapatan per kapita lebih rendah dari rata-rata kabupaten. Ada pun, klasifikasi wilayah menurut tipologi Klassen dapat dilihat pada tabel 2 .

Tabel 2. Tipologi Klassen

\begin{tabular}{ccc}
\hline \multicolumn{1}{|c}{} & $\mathbf{Y}_{\mathbf{i j}}>\hat{\mathbf{Y}}_{\mathbf{j}}$ & $\mathbf{Y}_{\mathbf{i j}}>\hat{\mathbf{Y}}_{\mathbf{j}}$ \\
\hline $\mathbf{g}_{\mathbf{i j}}>\breve{\mathbf{g}}_{\mathbf{j}}$ & $\begin{array}{c}\text { Kuadran III } \\
\text { Daerah } \\
\text { berkembang cepat }\end{array}$ & $\begin{array}{c}\text { Kuadran I } \\
\text { Daerah cepat maju } \\
\text { dan cepat tumbuh }\end{array}$ \\
\hline $\mathbf{g}_{\mathbf{i j}}<\breve{\mathbf{g}}_{\mathbf{j}}$ & $\begin{array}{c}\text { Kuadran IV } \\
\text { Daerah relatif } \\
\text { tertinggal }\end{array}$ & $\begin{array}{c}\text { Kuadran II } \\
\text { Daerah maju tapi } \\
\text { tertekan }\end{array}$ \\
\hline
\end{tabular}

\section{HASIL DAN PEMBAHASAN}

Berdasarkan hasil analisis static location quotient (SLQ) dan dynamic location quotient (DLQ), terlihat bahwa Kecamatan Tanjungsari selama periode 2011-2013 memiliki dua sektor unggulan dengan nilai SLQ dan DLQ lebih dari satu, yakni industri pengolahan dan bangunan. Sektor bangunan dan industri pengolahan menjadi sektor unggulan di wilayah ini akibat pengembangan saran dan prasarana di sekitar kawasan wisata pantai dalam tiga tahun terakhir. Dalam hal ini, kedua sektor tersebut dapat berperan sebagai sektor penunjang baik di masa sekarang maupun di masa datang. Pengembangan kedua sektor tersebut melalui pembangunan infrastruktur berupa akses jalan menuju lokasi pantai diharapkan dapat memaksimalkan geliat perekonomian masyarakat Kecamatan Tanjungsari di sekitar pantai.

Sementara itu, sektor pertanian merupakan sektor prospektif karena memiliki nilai SLQ lebih dari satu tetapi nilai DLQ kurang dari satu sehingga sektor ini tidak mampu diharapkan di masa datang meskipun saat ini merupakan sektor basis. Salah satu penyebabnya adalah daerah ini sering mengalami kekeringan di saat musim kemarau meski kondisi lahannya sangat cocok untuk pengembangan pertanian. Namun demikian, SLQ sektor pertanian bernilai lebih dari satu selama tiga tahun berturut-turut sehingga menjadi sektor basis dan mampu berjualan ke wilayah lain. Hal ini tak lepas dari adanya perkembangan lembaga keuangan mikro di daerah ini. Ada pun sektorsektor yang dikategorikan sebagai sektor prospektif, andalan, dan kurang prospektif dapat dilihat pada Tabel 3 . 
Tabel 3. Analisis Perbandingan Nilai SLQ dan DLQ Kecamatan Tanjungsari Rata-rata Tahun 2010-2013

\begin{tabular}{lccl}
\hline \multicolumn{1}{c}{ Lapangan Usaha } & SLQ & DLQ & \multicolumn{1}{c}{ Kategori } \\
\hline 1. Pertanian & 1,288218 & 0,067353 & Prospektif \\
2. Pertambangan \& Penggalian & 0,301206 & 1,36238 & Andalan \\
3. Industri Pengolahan & 1,034609 & 1,576251 & Unggulan \\
4. Listrik, Gas \& Air Bersih & 0,524111 & 2,955666 & Andalan \\
5. Bangunan & 1,019694 & 2,059498 & Unggulan \\
6. Perdagangan, Hotel \& Rest & 0,760653 & 1,084438 & Andalan \\
7. Pengangkutan \& Komunikasi & 0,459442 & 3,811885 & Andalan \\
8. Keu, Persewaan \& Jasa Pershn & 0,720223 & 0,66119 & Kurang Prospektif \\
9. Jasa-Jasa & 0,945181 & 1,872776 & Andalan \\
\hline
\end{tabular}

Sumber: data diolah

Pada Tabel 3 terdapat lima sektor andalan dengan nilai SLQ $<1$ dan DLQ $>1$, yakni pertambangan dan penggalian; listrik, gas, dan air bersih; perdagangan, hotel, dan restoran; pengangkutan dan komunikasi; dan jasa-jasa. Meskipun sektor-sektor tersebut belum dapat menunjang perekonomian di Kecamatan Tanjungsari di saat sekarang, sektor-sektor tersebut dapat dikembangkan untuk kemajuan ekonomi di masa datang. Sementara itu, sektor keuangan, persewaan, dan jasa perusahaan dikategorikan kurang prospektif karena nilai DLQ dan SLQ kurang dari satu sehingga belum dapat menunjang perekonomian di Kecamatan Tanjungsari.

Sementara itu, gambaran mengenai pola dan struktur ekonomi di Kecamatan Tanjungsari dapat dilihat melalui analisis Tipologi Klassen seperti yang tertera pada Tabel 4 .
Selama tahun 2011 hingga 2012, pola perekonomian Kecamatan Tanjungsari tidak bergeser dari kriteria berkembang yakni dengan pertumbuhan ekonomi di atas pertumbuhan ekonomi tingkat kabupaten dan pendapatan per kapita di bawah Kabupaten Gunungkidul. Namun demikian, turunnya kinerja perekonomian pada tahun 2013 telah berdampak pada perekonomian kecamatan menjadi daerah tertinggal dengan pertumbuhan ekonomi dan pendapatan per kapita di bawah level kabupaten. Implikasi kebijakan bagi daerah tertinggal adalah kebijakan sektoral yang diarahkan pada upaya penyediaan kesempatan kerja melalui pemanfaatan teknologi padat karya untuk industri pengolahan produk pertanian yang produk pasarnya luas, yakni bisa dijual ke luar daerah mengingat sektor industri pengolahan merupakan sektor unggulan.

Oleh karena itu, peran serta masyarakat dalam dunia usaha perlu digalakkan melalui

Tabel 4. Pola Ekonomi Kecamatan Tanjungsari, Gunungkidul Tahun 2011-2013

\begin{tabular}{cccccc}
\hline No & Tahun & $\begin{array}{c}\text { PDRB } \\
\text { (juta) }\end{array}$ & $\begin{array}{c}\text { Pertumbuhan Ekonomi } \\
\mathbf{( \% )}\end{array}$ & $\begin{array}{c}\text { Pendapatan per kapita } \\
(\mathbf{R p})\end{array}$ & $\begin{array}{c}\text { Kriteria } \\
\text { Kawasan }\end{array}$ \\
\hline 1 & 2011 & 130.184 & 4,58 & 5.053 .727 & Berkembang \\
2 & 2012 & 136.696 & 5,00 & 5.295 .216 & Berkembang \\
3 & 2013 & 142.436 & 4,20 & 5.475 .359 & Tertinggal \\
& Rata-rata & 136.438 & 4,59 & 5.274 .767 & Tertinggal \\
\hline \multicolumn{7}{c}{ Kabupaten Gunungkidul } \\
\hline
\end{tabular}

Sumber: data diolah 
peningkatan kapasitas berupa sarana dan prasarana dalam pemasaran produk. Kebijakan pengembangan industri tetap berorientasi pada industri yang tidak mencemari lingkungan dan tidak terpusat pada kawasan tertentu agar pertumbuhan industri dapat mengangkat pertumbuhan wilayah dan menyerap tenaga kerja di daerah tersebut dalam mengantisipasi terjadinya urbanisasi.

\section{SIMPULAN}

Sebagai bagian dari Kabupaten Gunungkidul yang berbatasan langsung dengan Samudera Hindia dan dilalui Jalan Jalur Lintas Selatan, Kecamatan Tanjungsari memiliki berbagai potensi yang dapat dikembangkan. Namun demikian, Kecamatan Tanjungsari mengalami pergeseran dari kawasan berkembang menjadi kawasan tertinggal. Salah satu alasannya adalah karena Kecamatan Tanjungsari bertumpu pada sektor pertanian yang meskipun menurut analisis SLQ merupakan sektor basis, namun menurut analisis DLQ sektor tersebut tidak mampu diharapkan di masa datang.

Maka dari itu, rencana pembangunan Kecamatan Tanjungsari sebaiknya lebih diarahkan ke sektor-sektor unggulan yang menjadi penunjang dalam perekonomian seperti industri pengolahan dan bangunan melalui terbangunnya infrastruktur berupa tempat pemasaran hasil industri pengolahan dan akses jalan menuju pantai karena kedua sektor tersebut merupakan sektor basis dan mampu menjadi penunjang di masa ini maupun yang akan datang.

\section{DAFTAR PUSTAKA}

Budiharsono, S. (2001). Teknik Pengembangan Wilayah Pesisir dan Lautan. Jakarta: PT Pradnya Paramita.

Cahyono, S.A. dan Wijaya, W.W. (2014). Identifikasi sektor ekonomi unggulan dan ketimpangan pendapatan antarkabupaten di sub DAS Bengawan Solo hulu. Jurnal Penelitian dan Ekonomi Kehutanan, 11, 3243.

Glasson, John. (1977). Pengantar Perencanaan Regional. Jakarta: Fakultas Ekonomi Universitas Indonesia.
Kadariah. (1985). Ekonomi Perencanaan. Jakarta: Lembaga Penerbit FE-UI.

Nazipawati. (2007). “Aplikasi Model Statik dan Dinamic Location Quotients dan Shift-Share dalam Perencanaan Ekonomi Regional (Studi Kasus Kabupaten Ogan Komering Ulu Provinsi Sumatera Selatan)". Ekonomi Regional 2(2): 81- 86.

Restiatun. (2009). Identifikasi sektor unggulan dan ketimpangan antarkabupaten/kota di Provinsi Daerah Istimewa Yogyakarta. Jurnal Ekonomi dan Studi Pembangunan, 10, 77-98.

Rustiadi, E., Saefulhakim, \& Panuju, D.R. (2011). Perencanaan dan Pengembangan Wilayah. Jakarta: Yayasan Pustaka Obor Indonesia.

Suyatno. (2000). Analisis Economic Base terhadap pertumbuhan ekonomi daerah tingkat II Wonogiri menghadapi implementasi UU No. 22/1999 dan UU No. 5/1999. Jurnal Ekonomi dan Pembangunan, I(2). FE Universitas Muhammadiyah Surakarta. 